\title{
Glosa do WYROKU WOJEWÓDZKIEGO SĄDU AdministracyJnego W BydgoszcZY Z DNIA 18 SIERPNIA 2020 R., SYGN. I SA/BD 101/20
}

Streszczenie. Komentarz poświęcony jest analizie wyroku Wojewódzkiego Sądu Administracyjnego w Bydgoszczy z dnia 18 sierpnia 2020 r., sygn. I SA/Bd 101/20. Rozpatrywane jest zagadnienie sposobu rozumienia art. 113 Ordynacji podatkowej, w myśl którego świadomość firmującego co do celu działania firmowanego podatnika przesądza o jego odpowiedzialności za zaległości podatkowe tego ostatniego. Autor krytycznie ocenia interpretację przepisu dokonaną przez sąd administracyjny, zwłaszcza w kontekście stanu faktycznego sprawy.

Słowa kluczowe: prawo podatkowe, sąd administracyjny, odpowiedzialność podatkowa, firmanctwo, Ordynacja podatkowa

* Profesor nauk prawnych, Uniwersytet Jagielloński (emeritus), e-mail: bogumil. brzezinski@uj.edu.pl,https://orcid.org/0000-0003-3923-5627 


\section{Świadomość firmującego co do celu działania firmowanego podatnika przesądza o jego odpowiedzialności za zaległości podatkowe tego ostat- niego na podstawie art. 113 Ordynacji podatkowej}

1. Zewnętrzny ogląd sprawy, do której odnosi się wyrok Wojewódzkiego Sądu Administracyjnego (WSA) w Bydgoszczy z dnia 18 sierpnia 2020 r., sygn. I SA/Bd 101/20, nie budzi istotnych wątpliwości. Nie budzi w sprawie wątpliwości to, że osoba skarżąca decyzję w sprawie odpowiedzialności na podstawie art. 113 Ordynacji podatkowej ${ }^{1}$ nie prowadziła pozarolniczej działalności gospodarczej, którą zarejestrowała, ale jedynie firmowała działalność gospodarczą innej osoby (podatnika). W rzeczywistości działalność ta prowadzona była wyłącznie przez podatnika i to on podejmował wszelkie decyzje jej dotyczące oraz ponosił pełne ryzyko związane z jej prowadzeniem. Można bez obawy popełnienia błędu powiedzieć, że skarżący był osobą firmującą działalność gospodarczą innej osoby (przedsiębiorcy-podatnika). Problem interpretacyjny, jaki tu się pojawia, sprowadza się do tego, czy firmujący, w realiach konkretnej sprawy, ponosi odpowiedzialność, jako tzw. osoba trzecia, za zaległości podatkowe podatnika na podstawie art. 113 o.p.

Sprawę można zaliczyć do kategorii hard case w rozumieniu dworkinowskim - tyle tylko że Sąd, w przeciwieństwie do oczekiwań wobec judykatury wyrażanych z nadzieją przez Ronalda Dworkina, herkulesowego zadania wydania dobrego rozstrzygnięcia nie podjął. Organy podatkowe oraz Sąd Administracyjny przyjęły, że w sprawie spełnione zostały wszystkie warunki uznania firmującego za osobę odpowiedzialną - na podstawie wskazanego wyżej przepisu - za zaległości podatkowe podatnika. Takie stanowisko Sądu jest nad wyraz dyskusyjne, a może nawet błędne.

2. Artykuł 113 o.p. stanowi, że jeżeli podatnik, za zgodą innej osoby, w celu zatajenia prowadzenia działalności gospodarczej lub rzeczywistych rozmiarów tej działalności posługuje się lub posługiwał imieniem i nazwiskiem, nazwą lub firmą tej osoby, osoba ta ponosi solidarną odpowiedzialność z podatnikiem całym swoim majątkiem za zaległości podatkowe powstałe podczas prowadzenia tej działalności.

Trzeba zaznaczyć, że nie ma iunctim między firmowaniem innej osoby a odpowiedzialnością firmującego. Najpierw musi się pojawić firmanctwo,

${ }_{1}^{1}$ Ustawa z dnia 29 sierpnia 1997 r. - Ordynacja podatkowa (Dz.U. z 2019 r., poz. 924 ze zm.), dalej: o.p. 
a dopiero potem można się zastanawiać nad tym, czy firmujący odpowiada za zaległości podatkowe firmowanego.

Zasadniczym elementem umożliwiającym zastosowanie art. 113 o.p. jest ustalenie znaczenia sformułowania: „za zgodą innej osoby, w celu zatajenia prowadzenia działalności gospodarczej lub rzeczywistych rozmiarów tej działalności”. Powstaje tu pytanie o znaczenie zgody oraz jej ewentualnego zakresu, a w dalszej kolejności - celu działania.

Zgoda (na coś) jest elementem wolicjonalnym, psychicznym. Jeśli jest elementem hipotezy normy prawnej, to należy ustalić jej zaistnienie w konkretnej sytuacji faktycznej. Trudność polega na tym, że wyrażenie (niewyrażenie) zgody nie jest układem binarnym, ale w określonej mierze stopniowalnym. Często jest ono - implicite bądź explicite - uwarunkowane (np. zakresem skutków jej wyrażenia). Na dodatek te skutki mogą być uświadomione ex ante, ale także ex post. Ponadto może istnieć różnica między tym, jaki jest zakres udzielonej zgody w przekonaniu udzielającego zgody, a tym, jak ten zakres będzie rozumiany przez odbiorcę - adresata komunikatu o wyrażeniu zgody. Dodatkowy kłopot może sprawiać potencjalna rozbieżność między elementem wolicjonalnym (tj. zgodą w sensie psychologicznym) a aktem postrzeganym przez otoczenie jako wyraz woli.

Dla sprawy najistotniejsze jest rozumienie pojęcia zgody na firmowanie innego podmiotu (podatnika - art. 113 o.p.) i jej zakresu.

W pierwszej kolejności trzeba podkreślić, że z opisu sytuacji zawartej w uzasadnieniu wyroku nie wynika dostatecznie jasno ani to, czy skarżący taką zgodę wyraził, a jeżeli tak, to jaki był zakres wyrażanej zgody, ani to, czy w ogóle był w stanie taką zgodę w sposób w pełni świadomy wyrazić. Trzeba pamiętać, że - jak wynika z uzasadnienia wyroku - presja ze strony pracodawcy na rozpoczęcie przez stronę działalności gospodarczej była początkowo uzasadniana przez tego pierwszego potrzebą dokonania oszczędności na kosztach pracy. Skoro proces rozwoju samozatrudnienia jako formy świadczenia pracy dotykał wówczas co najmniej setek tysięcy - jeśli nie większej liczby - Polaków, to takie działania zapewne znane były stronie skarżącej z obserwacji otoczenia, w którym funkcjonowała, a powszechność i ogólna aprobata dla rozwoju tego sektora rynku pracy mogła umacniać w przekonaniu, że założenie firmy jest nieuchronne, a nawet społecznie pożądane, odmowa grozi zaś utratą źródła utrzymania. Można jednak postawić pytanie, czy skarżący rozróżniał między tym, co miało być „firmą" jako podstawą prawną jego relacji z podatnikiem, a tym, co stało się firmą jako przykrywką działalności podatnika. 
3. Nie przesądzając w tym miejscu - z braku kompetencji merytorycznych - tej kwestii, należy wskazać na niejednoznaczność ocen stanu świadomości strony w sprawie wyrażanych przez rozmaite podmioty.

I tak Sąd Rejonowy Wydział Karny w Świeciu (w wydanym wcześniej wyroku uniewinniającym w sprawie karnej, w której skarżący w sprawie zakończonej glosowanym wyrokiem był wówczas oskarżonym), pisze: „Zauważono, że aby prowadzić tego typu działalność nakierowaną na oszustwa podatkowe, niezbędne było posiadanie odpowiedniej wiedzy w zakresie realiów działalności gospodarczej oraz systemu podatkowego i kontroli podatkowej. Zdaniem Sądu, takiej wiedzy nie posiadał Skarżący, nawet w podstawowym stopniu" (podkreśl. B.B.)².

Sąd Administracyjny w Bydgoszczy, oceniając zebrane w sprawie dowody, stwierdził: „Organ wskazał na istotne znaczenie, sporządzonej przez biegłych lekarzy opinii sądowo-psychiatryczno-psychologicznej Skarżącego, z której wynikało, że w funkcjonowaniu społecznym cechowała go niezaradność życiowa, pozwalanie innym na podejmowanie decyzji w ważnych osobistych sprawach, niechęć do stawiania sobie racjonalnych wymagań, ograniczona zdolność do podejmowania decyzji w zwyczajnej codzienności, postrzeganie siebie jako bezradnego, nadmierna uległość wobec innych. Wnioski z tej opinii organ ocenił jako zbieżne ze złożonymi w postępowaniu zeznaniami matki Skarżącego, S.D., oraz jego siostry, K.D.”

W odniesieniu do opinii biegłych w narracji uzasadnienia widoczne są istotne, a zarazem trudno wytłumaczalne niespójności. Gwoli sprawiedliwości należy dodać, że każdej praktycznie narracji (nawet stosowanej w tej glosie) można zarzucić jakieś braki, ale co najmniej zdziwienie budzić musi to, że bezpośrednio po fragmencie wyżej przytoczonym znajduje się taka oto konkluzja, którą Sąd - nie kontestując - uznaje za zasadną: „Na tej podstawie [tj. opinii biegłych - B.B.] organ przyjął, że Skarżący jakkolwiek nie prowadził w istocie rzeczy działalności gospodarczej, nie osiągał z tego tytułu przychodów, nie dokonywał czynności podlegających opodatkowaniu podatkiem od towarów i usług, to ponosił odpowiedzialność za zaległości podatkowe jako osoba trzecia w świetle art. 113 Ordynacji podatkowej”.

Czy to oznacza, zdaniem Sądu, że jeśli osobnik jest nieporadny/bezradny („na tej podstawie organ przyjął...”), to stanowi to podstawę do aprobowanego przez Sąd uznania istnienia odpowiedzialności (ze względu na wskazane wyżej cechy) takiego osobnika jako firmującego? Dalszy komentarz wydaje się zbędny.

${ }^{2}$ Cyt. za uzasadnieniem glosowanego wyroku. 
Wracając w tym momencie do oceny ogólnej sprawy, można mieć uzasadnioną wątpliwość co do tego, czy w świetle przedstawionych przez biegłych (kilku!) ocen możliwości intelektualnych podatnika broni się teza o świadomiej zgodzie firmującego, a w szczególności o świadomości sytuacji, w jakiej na skutek tej zgody się on znajdzie, i jej prawnych konsekwencji. Tego niestety Sąd dogłębnie nie rozważył.

4. Wydaje się, że określenie strony jako osoby bezwolnej, podatnej na sugestie otoczenia i mającej „ograniczoną zdolność do podejmowania decyzji w zwyczajnej codzienności” (!) jest tu adekwatne do charakterystyki osobowości skarżącego. W związku z tym, przed dokonaniem dogmatycznej analizy art. 113 o.p. należy postawić pytanie, czy taki osobnik: (a) był w stanie odmówić prośbie/sugestii/żądaniu pracodawcy „otwarcia” własnej działalności gospodarczej i (b) czy był w stanie przewidzieć skutki takiego postępowania? Odpowiedź w obu wypadkach brzmi: nie.

Organy podatkowe przyjęły, że w sprawie zakończonej glosowanym wyrokiem zaszły okoliczności podatkowoprawnego (a nie, jak błędnie pisze Sąd - prawnopodatkowego) stanu faktycznego, odpowiadające (moim zdaniem jedynie prima vista) opisowi zawartemu w art. 113 o.p. Stąd decyzja o odpowiedzialności firmującego jako tzw. osoby trzeciej, zaaprobowana przez Sąd w glosowanym wyroku.

Sąd pisze: „Należy jednocześnie zauważyć, że jak wynika z tez opinii biegłych przytoczonej w uzasadnieniu włączonego do akt sprawy wyroku Sądu Rejonowego w Ś., Skarżący mimo ujawnionych cech osobowości jak uległość wobec innych, pozwalanie innym na decydowanie w ważnych sprawach osobistych był w stanie dokonać krytycznej oceny sytuacji i przewidzieć następstwa określonych działań”.

I takie stanowisko przesądza - zdaniem Sądu - sprawę. Osobnik, który ma problemy z ułożeniem sobie życia codziennego, intelektualnie i emocjonalnie niesamodzielny, potrafi - zdaniem biegłych - orientować się w zagadnieniach prawnych z zakresu odpowiedzialności osób trzecich za zobowiązania podatkowe - zagadnieniach, którym poświęcono niejedną monografię naukową ${ }^{3}$. Jednym słowem - prawniczy talent. Dokonuje on „krytycznej oceny sytuacji” i „przewiduje następstwa określonych działań”. Jakich - nie wiadomo; wiadomo tylko, że „określonych”.

${ }^{3}$ Zob. np. A. Olesińska, Odpowiedzialność osób trzecich za zobowiązania podatkowe, Torun 1994; eadem, Odpowiedzialność osób trzecich za zobowiązania podatkowe, Lublin 2000. 
I to pół zdania opinii biegłych zaważyło na rozstrzygnięciu sprawy przez Sąd. Sąd nie odważył się na konfrontację tej połowy zdania z całym zespołem argumentów przeciwnych - także zawartych w opinii biegłych. Bezrefleksyjność sądu budzi tu prawdziwe zdumienie.

5. Sąd pisze w uzasadnieniu wyroku tak oto: „W orzecznictwie sądowoadministracyjnym na tle analogicznych okoliczności faktycznych jak ustalone $\mathrm{w}$ rozpoznawanej sprawie zaprezentowano - adekwatny $\mathrm{w}$ niniejszej sprawie - pogląd, że świadoma zgoda firmującego na firmanctwo, z uwagi na potrzebę utrzymania źródła utrzymania uzasadnia jego odpowiedzialność na podstawie art. 113 Ordynacji podatkowej (por. wyrok WSA w Szczecinie z dnia 5 sierpnia 2015 r., sygn. akt I SA/Sz 49/15, publ.: Centralna Baza Orzeczeń Sądów Administracyjnych, www.orzeczenia.nsa. gov.pl, dalej: CBOSA), co znalazło potwierdzenie w toku kontroli instancyjnej (por. wyrok NSA z dnia 19 lipca 2017 r., sygn. akt I FSK 2114/15, publ.: CBOSA)".

Stwierdzenie, że w obu sprawach, tj. rozstrzygniętej w I instancji wyrokiem WSA w Szczecinie oraz w sprawie rozstrzygniętej glosowanym wyrokiem, występowały analogiczne okoliczności faktyczne, znalazło się w bezpiecznej odległości od tego, co nazywane jest prawdą. W powołanym wyroku Naczelnego Sądu Administracyjnego (NSA) ocena tych okoliczności jest bowiem następująca: „Skarżący, co wynika z wcześniejszych wywodów tut. Sądu, nie podważył w sposób skuteczny ustalonego przez organy i przyjętego przez WSA stanu faktycznego sprawy. Organy uznały natomiast, że Skarżący, kierując się różnymi motywami osobistymi, założył działalność gospodarczą, w ramach której wszelkie działania oraz obowiązki dokumentacyjne prowadził A.S. Ponadto organy nawiązały do wypowiedzi Skarżącego, który sam przyznał, że powodem jego działania była konieczność utrzymania rodziny oraz wdzięczność A.S. za okazaną wcześniej pomoc".

Jeśli odnosić się do motywów działania osób firmujących, to poza sporem pozostaje to, że czym innym jest działanie $z$ konieczności utrzymania rodziny i wdzięczność za okazaną wcześniej przez podatnika pomoc, a czym innym niemożność czy brak psychicznej zdolności oparcia się perswazji i sugestiom pracodawcy w niewielkiej firmie na prowincji przez osobę o umiarkowanych walorach intelektualno-emocjonalnych. W związku z powyższym powołanie się na wyrok NSA być może utwierdza Sąd w dokonanym wyborze interpretacyjnym, ale może tylko maskuje ewentualne wahania w tej 
kwestii. Rzetelność powoływania w tym wypadku wspomnianego wyroku NSA stoi w każdym razie pod dużym znakiem zapytania.

6. Powołanie wspomnianego wyroku NSA w glosowanym wyroku ma jednak i dobrą stronę: pokazuje, że ten ostatni sąd bierze pod uwagę motywy firmującego przy wykładni art. 113 o.p. W konkretnej sprawie podawane przez firmującego motywy NSA uznał za niewystarczające.

Jeśli jednak bierze on pod uwage motywy (o czym wyraźnie mowa w uzasadnieniu wyroku kasacyjnego), to, logicznie rozumując, brałby też pod uwagę kwestię świadomości sytuacji osoby firmującej działanie podatnika. Z punktu widzenia psychologii jednostki w pierwszej bowiem kolejności należy uwzględniać świadomość własnej sytuacji, a dopiero potem można (dostrzegając sytuacyjne ograniczenia) dobierać sobie określone motywy działania.

W sprawie zakończonej glosowanym wyrokiem Sąd - w ślad za organami podatkowymi - przyjął rozwiązanie intelektualnie najprostsze: skoro firmował, to znaczy, że się na to zgadzał. Dowody moim zdaniem dobitnie świadczące o ograniczeniach mentalnych skarżącego uznane zostały za niewystarczające dla uwolnienia go od odpowiedzialności przez organy podatkowe, a następnie Sąd.

Podstawową słabością - żeby nie rzec błędem - interpretacji art. 113 o.p. dokonanej zarówno przez organy administracji podatkowej, jak i ulegający płynącej z tej strony sugestii Sąd było uznanie, że wystarczy ustalenie, jako przesłanki odpowiedzialności, iż działanie podatnika (firmowanego) miało na celu zatajenie prowadzonej przez niego działalności, albo też jej rozmiarów. Organ co prawda przyjął, że podatnik tak działał, ale z tego nic jeszcze samo przez się nie wynika.

Sąd nie dostrzegł, że zgoda firmującego (jako warunek jego odpowiedzialności) musi obejmować negatywnie oceniane okoliczności, jak cele działania podatnika, wyrażające się zatajeniem prowadzenia działalności gospodarczej lub rzeczywistych rozmiarów tej działalności. Inaczej mówiąc, firmujący musi wyrazić zgodę (co wymaga wcześniejszej świadomości stanu rzeczy, jaki ta zgoda wywoła), czyli godzić się na to, że cała operacja prowadzi do „zatajenia prowadzenia działalności gospodarczej lub rzeczywistych rozmiarów tej działalności”.

Czy zgodę na coś takiego wyraził skarżący? Z uzasadnienia wyroku nic takiego nie wynika. Zgodził się być może w pewnym momencie na to (pamiętać należy, że jego firma została założona w związku z deklarowaną 
przez pracodawcę potrzebą optymalizacji kosztów pracy), że będzie firmować działalność swojego pracodawcy (podatnika), ale gdzie i w czym miałaby wyrażać się zgoda na zatajenie działalności gospodarczej lub rzeczywistych rozmiarów tej działalności? Można mniemać - biorąc udowodnione możliwości intelektualne skarżącego - że było wręcz przeciwnie: skoro jakaś działalność gospodarcza (sprzedaż) była dokumentowana podpisywanymi przez niego fakturami (autentycznymi, jak - wbrew nadziejom organów podatkowych - okazało się w procesie karnym) oraz dokumentacją podatkową jego „firmy”, to o ukrywaniu działalności w jego mniemaniu nie mogło być mowy, bo przecież nie po to wystawia się faktury i składa deklaracje podatkowe, żeby ukryć działalność nimi objętą.

Powinno się liczyć to, na co godził się skarżący, i to, jaką miał świadomość „podatkowych” relacji z pracodawcą. A godził się (i następnie to czynił) na podpisywanie dokumentów - faktur, dokumentów rejestracyjnych czy rozliczeniowych, spośród których nie wszystkie - obiektywnie, bo niekoniecznie w świadomości strony - odzwierciedlały rzeczywistość. W uzasadnieniu wyroku nie ma natomiast ani śladu wnioskowania co do tego, że firmujący godził się („za zgodą”) na „zatajenie prowadzenia działalności gospodarczej lub rzeczywistych rozmiarów tej działalności”. Ta materialnoprawna przesłanka nie została wykazana: organy podatkowe przyjęły mechanicznie, że jak się zgodził - to na wszystko. Takie podejście jest metodologicznie błędne, gdyż odnosi się do tego, co ewentualnie robi firmowany, a przepis odnosi się do tego, czy zgadza się na to firmujący.

Jeżeli firmowany korzysta $\mathrm{z}$ „usług” firmującego, to można powiedzieć przynajmniej, że nie ujawnia działalności własnej (albo ujawnia ją częściowo). Nawet tutaj można by się zastanawiać, czy działalność objęta firmanctwem jest „zatajana” - jest ona przecież jako taka jawna, a jej rezultaty są poddane opodatkowaniu (do momentu odkrycia firmanctwa przez organy podatkowe na imię firmującego, a następnie, w skrócie - na imię rzeczywistego podatnika) - tyle że prezentowana „na zewnątrz” pod inną firmą... ${ }^{4}$ Wymaganie od skarżącego (w kontekście obrazu jego osobowości), aby dostrzegał zatajanie (i z tym się godził) w czymś, co jest oczywiście i poza sporem ujawniane w dokumentacji prowadzonej przez niego firmy, to zadanie, które może postawić mu jedynie albo biegły, albo Sąd, albo oba te podmioty łącznie.

${ }^{4}$ Chodzi mi tutaj o kwestię leksykalną, a nie o to, czy firmanctwo jest naganne i jak powinno być traktowane przez system prawny. 
Z doświadczenia wiadomo, że zawsze łatwiej określać wymagania innym niż sobie samemu. Uzasadnienie glosowanego wyroku jest dobrym tego przykładem.

7. Fakt - przytaczany przez organy podatkowe i niekwestionowany przez Sąd - że skarżący podejmował czynności firmujące mimo sprzeciwu matki - może być oceniany inaczej, niż miało to miejsce w sprawie. Co prawda sprzeciwianie się matce przynosi niekiedy opłakane rezultaty, ale czy nie można tego interpretować w taki sposób, że sprzeciwiał się nawet matce, gdyż był głęboko przekonany, iż jego „gospodarcza” aktywność nie niesie za sobą żadnych szkód i zagrożeń, bo nie prowadzi do ukrycia jakiejkolwiek działalności gospodarczej? A na taki stan rzeczy (tj. ukrywanie) skarżący być może się nie godził? To ostatnie nie zostało przekonująco wyjaśnione, a przecież to właśnie wystarczy do wyłączenie jego odpowiedzialności za firmanctwo.

Strona (skarżący) miała podstawy, aby uważać, że „nie robi nic złego”. Niekiedy jednak jednostka ponosi skutki - i to dotkliwe dla niej - „nierobienia niczego złego”. Żeby ją od tego uchronić, potrzebna jest niekiedy pogłębiona analiza prawnicza. A ta prowadzi do wniosku, że w sprawie nie wykazano - odmiennie od tego, co przyjął Sąd - spełnienia wszystkich przesłanek odpowiedzialności podatkowej za firmanctwo, o jakich jest mowa w art. 113 o.p.

8. Sąd, niestety, moim zdaniem nie sprostał zadaniu interpretacyjne$\mathrm{mu}$, przed jakim stanął. Zmartwiłoby to niewątpliwie Ronalda Dworkina - gdyby staruszek profesor jeszcze żył. Na dodatek Sąd próbuje w uzasadnieniu „oklepać” stronę skarżącą powołaniem się na stanowisko zajęte uprzednio przez NSA w sprawie - jego słowami - analogicznej, która analogiczna w żadnym wypadku nie jest, ponieważ wyroki dotyczą odmiennych stanów faktycznych.

Analiza orzecznictwa podatkowego sądów prowadzi do wniosku, że strategia „oklepywania” strony skarżącej jest stosowana wówczas, gdy sąd nie ma przekonania do własnego rozstrzygnięcia (w kontekście prawidłowej interpretacji relewantnych do stanu faktycznego sprawy przepisu) albo gdy rozstrzygnięcie $\mathrm{w}$ kategoriach dogmatycznoprawnej analizy prawniczej jest (bądź tylko wydaje się sądowi) poprawne, ale w osobie podejmującej decyzję interpretacyjną budzi mimo wszystko sprzeciw ze względów aksjologicznych. 
„Oklepywanie” (przepraszam za kolokwializm, ale prawidłowy termin na to zjawisko powinna wypracować ogólna teoria prawa pospołu z psychologią i socjologią prawa) strony (zazwyczaj podatnika) polega na tekstowym „rozwadnianiu” rozstrzygnięcia w treści jego uzasadnienia. Najczęściej przybiera ono postać wielostronicowych opisów stanu faktycznego sprawy rozciągniętych w czasie od lat panowania Mieszka II do wydania decyzji ostatecznej przez organ odwoławczy, natręctwa interpretacyjnego wyrażającego się w pogłębionych (bez znaczenia dla istniejącego stanu faktycznego rozpatrywanej sprawy) analizach relewantnych przepisów wraz z przyległościami (często $\mathrm{z}$ naciskiem na przyległości) oraz kopiowaniu fragmentów treści w istocie podręcznikowych itp., itd. ${ }^{5}$

Być może jest wyrazem przekonania sądów, że lekarstwo rozcieńczone jest mniej gorzkie, a może też przekonania, że rozczarowana wyrokiem strona, stykająca się z tekstem przypominającym jedną z tasiemcowych powieści J.I. Kraszewskiego pomyśli, iż w wyroku jest jednak coś na rzeczy (skoro tyle da się o sprawie napisać...). Sędziemu - być może - wydaje się wówczas, że im więcej napisze w uzasadnieniu, tym mniej bolesna dla ofiary przepisów będzie percepcja rozstrzygnięcia, a może nawet nastąpi akt mentalnego pogodzenia się z zapadłym wyrokiem. Warto jednak zauważyć, że „sędzia-oklepywacz” to nie to samo co "pilot-oblatywacz”... Ten drugi może, i powinien, okazać swój kunszt po starcie, ten pierwszy powinien to robić raczej przed wydaniem wyroku - wtedy nie musiałby sięgać po instrumenty oklepywania podatnika.

Czy te nadzieje sądowego interpretatora są uzasadnione, a nawet czy powyższe supozycje odpowiadają rzeczywistości - trudno w tym miejscu wyrokować. Być może istnieje inne jeszcze uzasadnienie fenomenu „oklepywania” strony przegrywającej proces. Jego zbadanie mogłoby być wdzięcznym przedmiotem nie tylko dla nauki prawa, ale także np. dla Biura Orzecznictwa NSA.

W glosowanym wyroku „oklepywanie” skarżącego ma miejsce w stopniu umiarkowanym, ale oczywiście dostrzegalnym. Jego elementy uwidaczniają się nie tylko we wprowadzającym w błąd odwoływaniu się do wcześniejszego orzecznictwa, ale także w uporczywym przekonywaniu (nie wiadomo kogo), że skarżący nie prowadził, i wręcz nie mógł prowadzić, działalności

5 „Oklepywanie” strony przegrywającej spór sądowy nie jest bynajmniej wynalazkiem WSA w Bydgoszczy, lecz ma znacznie szerszy zasięg; zob. B. Brzeziński, Glosa do wyroku WSA w Lublinie z 22.01.2019 r. (I SA/Lu 48/19), „Przegląd Orzecznictwa Podatkowego" 2019, nr 4, s. 255 i n. 
gospodarczej. To oczywiście prawda, ale przecież wywiódł to w sposób całkowicie zadowalający organ podatkowy w decyzji ostatecznej, a skarżący tej okoliczności nie kwestionuje...

9. Na marginesie (bo nie ma to znaczenia dla sprawy) dodajmy: zasadniczo błędny jest pogląd, że odpowiedzialność firmującego za zaległości podatkowe firmowanego jest rodzajem sankcji podatkowej. Za co niby miałaby być ta sankcja? Przecież gdyby podatki od prowadzonej przez firmowanego działalności były zapłacone, nikt nie miałby pretensji do firmującego (przynajmniej w kategoriach prawa podatkowego), gdyż nie byłoby zaległości podatkowej (art. 113 o.p.). A jeśli nie są zapłacone, to system podatkowy poszukuje rekompensaty finansowej z tego tytułu i - w przypadku art. 113 o.p. - uznaje, że związek firmującego ze sprawą niezapłaconych przez firmowanego podatków jest na tyle istotny, że rekompensata jest należna właśnie od tego pierwszego. Ordynacja podatkowa nie zawiera wyrażonego expressis verbis zakazu firmanctwa: przewiduje jedynie niekorzystne dla firmującego skutki w sytuacji, gdy firmowany dopuszcza do powstania zaległości podatkowych. Przeciwko uznaniu sankcyjnego charakteru odpowiedzialności osób trzecich (w tym także firmującego) przemawia kształt mechanizmu odpowiedzialności, wynikający $\mathrm{z}$ przepisów Ordynacji podatkowej (vide art. $108 \$ 2$ i 4 o.p.).

Sąd, wyrażając pogląd o sankcyjnym charakterze odpowiedzialności osób trzecich, powołuje się na jakąś bliżej nieokreśloną literaturę. Co prawda nie ma powodu, aby wątpić w informację Sądu co do istnienia tego rodzaju poglądów w piśmiennictwie, ale na to jest tylko jedna rada: należy zmienić lektury na bardziej miarodajne.

\section{BIBLIOGRAFIA}

Brzeziński B., Glosa do wyroku WSA w Lublinie z 22.01.2019 r. (I SA/Lu 48/19), „Przegląd Orzecznictwa Podatkowego" 2019, nr 4.

Olesińska A., Odpowiedzialność osób trzecich za zobowiązania podatkowe, Toruń 1994.

Olesińska A., Odpowiedzialność osób trzecich za zobowiązania podatkowe, Lublin 2000. 
The Commentary of the judgment of the Provincial Administrative Court in Bydgoszcz of August 18, 2020 (I SA/BD 101/20)

Summary. The commentary is devoted to the analysis of the judgment of the Provincial Administrative Court in Bydgoszcz of August 18, 2020 (I SA/Bd 101/20). The issue is understanding of Art. 113 of the General Tax Law (1997), according to which the awareness of the person who illegally represents of taxpayer as to the purpose of activity of the latter determines its responsibility for the tax arrears. The author criticizes the interpretation of the provision by tax court, especially in the context of the facts of the case.

Keywords: tax law, tax liability, tax court, illegal representation of other person, Tax Ordinance 